\title{
Importance of Forest Ecosystem Services to Secondary School Students: a Case from the North-West Slovenia
}

\author{
Gregor Torkar ${ }^{1,2 \Xi}$, Andrej Verlič ${ }^{3}$, Urša Vilhar $^{3}$
}

\author{
${ }^{1}$ University of Ljubljana, Faculty of Education, Kardeljeva ploščad 16 , SI-1000 Ljubljana, Slovenia \\ 2 University of Nova Gorica, School of Environmental Sciences, Vipavska 13 , SI-5000 Nova Gorica, Slovenia \\ ${ }^{3}$ Slovenian Forestry Institute, Večna pot 2, SI-1000 Ljubljana, Slovenia \\ ${ }^{\star}$ Corresponding author: e-mail: gregor.torkar@pef.uni-lj.si; gregor.torkar@ung.si
}

Citation:

TORKAR G, VERLIČ A, VILHAR U 2014 Importance of Forest Ecosystem Services to Secondary School Students: a Case from the North-West Slovenia. South-east Eur for 5 (1): 35-43. DOI: http://dx.doi.org/10.15177/seefor.14-02

Received: 7 Apr 2014; $\quad$ Accepted: 9 May 2014; $\quad$ Published online: 19 May 2014

\begin{abstract}
Background and Purpose: Forest managers are facing challenges in balancing the demands for forest social services raised by the general public and forest productive services. Knowing local people's attitudes, taking into account their needs and respecting their opinions, introducing social aspects should become a management priority to ensure success of conservational activities and sustainable use of natural resources. This study investigates the attitudes of one category from the general public which is secondary school students related to forest ecosystem services in order to determine and present a useful basis for further research of people's attitudes towards forests and forest management.

Materials and Methods: In 2013 and 2014410 Slovenian students from secondary schools in the Vipava valley and Goriška area in northwestern Slovenia completed a questionnaire testing for the influence of gender and frequency of forest experiences on attitudes to forest ecosystem services. Students' attitudes to forest ecosystem services were investigated via 15 statements about provisioning, regulating, cultural and supporting services. The gathered data was analysed by the Statistical Package for the Social Sciences (SPSS), using ANOVA, Tukey post-hoc test, Spearman's product moment correlation and the nonparametric Mann-Whitney (U) test.

Results and Conclusions: Students acknowledged the high benefits of ecosystem services provided by forests, though not all forest ecosystem services hold the same importance to secondary school students. Students placed the highest importance on supporting services; especially on the value of forests as habitats for animal and plant species. Also the importance of forests for clean air production was emphasized. Students with more frequent experiences in the forest environment placed more importance on cultural services as well as regulating services, especially for clean water and air production. Gender differences were not significant, other than in the valuation of the forest as a place for relaxation and reflection, where female students were more supportive than male students.
\end{abstract}

Keywords: ecosystem services, forest, attitudes, secondary school students 


\section{INTRODUCTION}

Forests are identified as key landscape elements for the provision of many environmental services provided, such as flood regulation [1], moderation of the urban climate [2], air pollution reduction [3] and biodiversity conservation [4]. Worldwide, approximately $60 \%$ of the ecosystem services are being degraded or used unsustainably, including fresh water, capture fisheries, air and water purification, and the regulation of regional and local climate, natural hazards, and pests [5]. The full costs of the loss and degradation of these ecosystem services are difficult to measure, but the available evidence demonstrates that they are substantial and growing. These trade-offs often shift the costs of degradation from one group of people to another or defer costs to future generations (ibid.). For these reasons managing forests is highly participatory, aiming to become multifunctional and multidisciplinary, involve experts from natural as well as social sciences, and geared toward developing partnerships between all stakeholders.

Alarming environmental changes, such as extinction of species and environmental degradation, encouraged scientists to begin promoting the idea of services offered to humans by biodiversity and natural systems in order to get support for conservation [6]. In a highly influential paper by Costanza et al. [7], they calculated the economic value of 17 ecosystem services in order to raise the importance of these issues. The concept of ecosystem services is the way to communicate societal dependence on ecological life support systems [8].

With almost $63 \%$ of the land mass covered by forest, Slovenia is the third most forested country in Europe [9]. Consequently, forests are an essential feature and a constituent of Slovenia's environment and hold a high protective and social significance [10]. For a considerable length of time, forest management was based on the paradigms of sustainability, close-to-nature management and multifunctionality, all of which have been implemented through the hierarchically organized system of forest management plans [11]. Until recently, the main objective of forest management was to secure sustainability of all forest ecosystems, regardless of ownership and their productive roles, ignoring the needs and preferences of the general public as one of the main stakeholder groups [12]. Given the great natural and socio-economic diversity of forest conditions in Slovenia, the key for ensuring sustainable forest management and the multifunctional role of forests is the development of a decentralized integrated approach (the 'bottom-up approach' and 'multi-stakeholder process') [13]. Therefore, public participation in the decision-making process should be introduced in order to favour a dialog in civil society on all forestry related topics (ibid.).

Despite immense natural capital and ecosystem services that flow from it, only few studies comprehensively address human attitudes toward ecosystem services and values provided by forests [14-18]. In order to make an informed decision, forest managers need an understanding of the benefits local residents would like the resource to produce [18]. Lindemann-Matthies with others [15] investigated the attitudes of Chinese and Swiss people, both environmental experts and laypersons, toward forest biodiversity and ecosystem services. They found out that all participants highly valued the forest ecosystem services, especially the regulating and supporting services. They also found out that city dwellers and forest visitors placed more importance on the regulating services, whereas environmental science students and farmers placed more importance on the provisioning services. Similarly, Gao with others [14] found that ecosystem services were important to local residents in Southeast China and were the motivation to protect culturally important forests. Participants especially valued cultural services which they mostly use and benefit from in these forests.

Knowing local people's attitudes, taking into account their needs, and respecting their opinions should become a management priority for success of conservational activities and sustainable use of natural resources [19]. Schools should develop students' knowledge, attitudes and responsible behaviour towards the environment and nature [20] in order to improve the forestry related decision-making processes in the future. Therefore, 
the aim of the present study was to investigate attitudes of secondary school students toward forest ecosystem services in NW Slovenia. The main research questions were (a) how students value different forest ecosystem services, (b) why students visit forests, (c) does gender influence valuation of ecosystem services and (d) how frequency of experiences in the forest ecosystems affect their valuations.

\section{MATERIAL AND METHODS}

\section{Study Area}

The study area of $2200 \mathrm{~km}^{2}$ is located in northwest of Slovenia, and includes municipalities within Tolmin Slovenian Forest Service Regional Unit (Figure 1). The climate is subMediterranean in the southern part and sub - Alpine in the northern part. The highly heterogeneous landscape con-sists of rivers, valleys, hills, mountains and steep limestone walls. The complex terrain ranges from $50 \mathrm{~m}$ above sea level in the lowlands to the highest point in Slovenia - mount Triglav (2 $864 \mathrm{~m}$ ). Forests cover $67 \%$ of the area. Lamio orvalae-Fagetum praealpinum, Enneaphyllo-Fagetum, Anemone-Fagetum, Larici-
Fagetum, Abieti-Fagetum dinaricum, ClematidiAbietetum, Lycopodio-Abietetum, FestucoAbietetum, Carici albae-Fagetum, Calamagrostido variae-Fagetum, Seslerio-Ostryetum [21] are the most represented forest associations. According to the forest management plans for the Tolmin Regional Unit, the most important forest functions are wood production, protection of soils, forest stands and infrastructure, as well as recreation and tourism [22]. This study area was chosen because it well represents the diversity of forests present in Alpine, Submediterranean and Dinaric phytogeographical regions [23].

\section{Sample}

In fall 2013 and winter 2013-2014, first and second year Slovenian students attending randomly selected secondary schools in Vipava, Ajdovščina and Nova Gorica were questioned via a self-administered questionnaire ( $N=410)$. More than $90 \%$ of students from this study area attend secondary schools in selected towns [24]. The sample consisted of 134 (32.7\%) males and $276(67.3 \%)$ females. Their average age was 15.64 years $(S D=0.59, \operatorname{Min}=15, \operatorname{Max}=18)$. At all data collection steps, full anonymity was guaranteed to the participants.

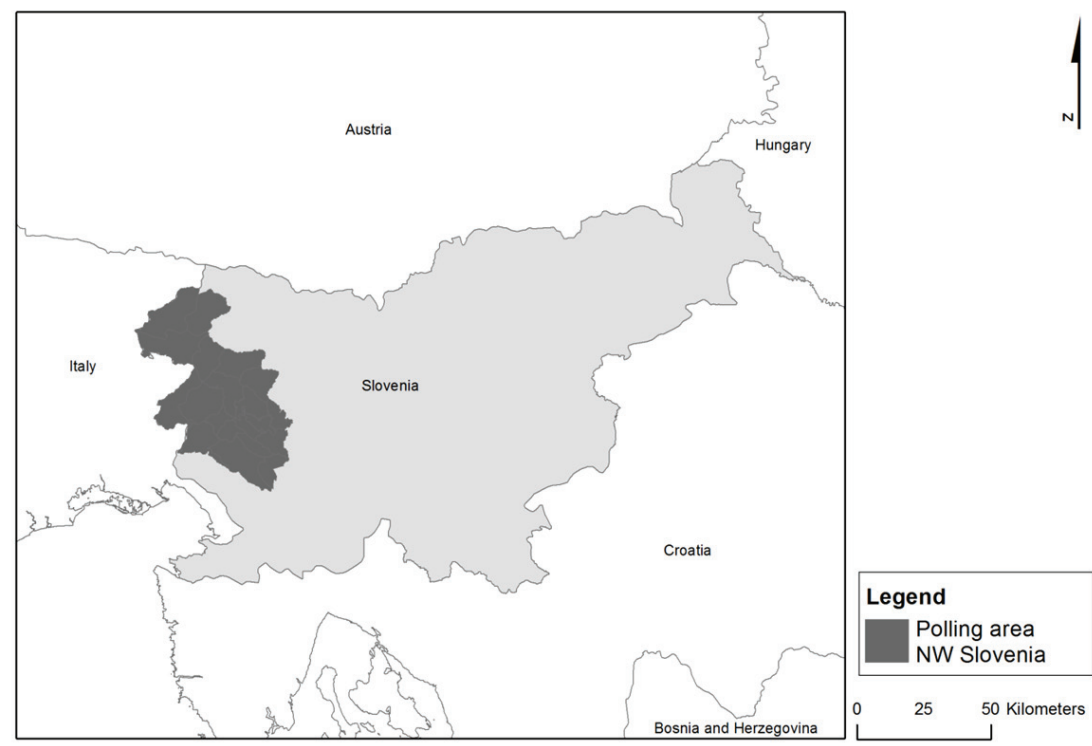

FIGURE 1. Polling area 


\section{Design and Procedure}

All selected secondary schools are situated in Vipava valley and Goriška area in northwest of Slovenia (Figure 1). Schools were contacted by phone and later visited by a researcher, who provided printed copies of the questionnaire and instructions for teachers. Teachers conducted questioning in the classrooms, at the beginning of science or biology lessons.

The students were asked to complete a questionnaire which allowed us to test for the influence of gender and frequency of experiences in the forest on attitudes toward forest ecosystem services. Student's attitudes toward forest ecosystem services were investigated with the help of 15 statements about provisioning (A), regulating (B), cultural (C) and supporting (D) services, as defined by the Millennium Ecosystem Assessment [5]. Specific ecosystem services are described in Table 2 . The statements were adopted from the study by LindemannMatthies with others [15] (for statements see Table 1). For each service, students answered on five-step Likert scales (1- unimportant, 2somewhat unimportant, 3- neither unimportant nor important, 4- somewhat important and 5important) [25]. Five-step Likert scale was also used to collect information about the frequency of experiences in the forest ("How often do you visit forests?": 5- several times a week, 4- weekly, 3- twice a month, 2- monthly, 1- rarely). Students also answered open-ended question asking them to name their reasons for visiting the forests. Their answers were then categorized as cultural, provisioning, regulating or supporting services, and the frequency of answers in each category was calculated.

\section{Data Analyses}

Data entry and analysis was conducted using the Statistical Package for the Social Sciences (SPSS). ANOVA and Tukey post-hoc test were used to analyze student's attitudes toward specific forest ecosystem services. Spearman's product moment correlation ( $r s$ ) coefficient was used for exploring the relationship between attitudes toward forest ecosystem services and the frequency of experiences in the forest. The nonparametric Mann-Whitney (U) test was used to test for significant gender differences in attitudes toward forest ecosystem services.

\section{RESULTS}

Results show that not all forest ecosystem services have the same importance to secondary school students (Figure 2) $(\mathrm{F}=45.88, \mathrm{p}<0.001)$. Multivariate testing of differences between ecosystem services was used (Supplementary material 1 - http://www. seefor.eu/supp_material/torkar_et_al_1.pdf.) In general, students placed the highest importance on supporting services; especially on the value of forests as habitats for animal and plant species (D1, D2). The value they placed on forests as habitats for mushrooms is significantly lower than that for animals and plants. They also placed high importance on regulating services. Importance of forests for the production of clean air is especially emphasized. Surprisingly, they placed a lower importance on provisioning services compared to supporting and regulating services. Importance of the forest for food production was significantly lower to students compared to the role forests play in wood and fuel production. The students placed the lowest importance on cultural services. The lowest score was placed on the aesthetic value, which the students ranked significantly lower than the other three cultural services of forests.

Students were asked how frequently they visit forests (Figure 3). Half of the students visit forests weekly or multiple times a week. The reasons for visiting forests were divided into four categories of ecosystem services: provisioning, regulating, cultural and supportive. The main reasons for visiting the forests fall into the category "cultural services" ( $f=343$ ); most of these students use forests for walking, running and relaxation. In the category "provisioning services" ( $f=30$ ) students mentioned logging and mushroom picking. Fresh air is the only reason for visiting forests in the category "regulating services" ( $f=29$ ). In the category "supportive services" ( $f=10$ ) students mentioned observation of nature, animals and plants. 


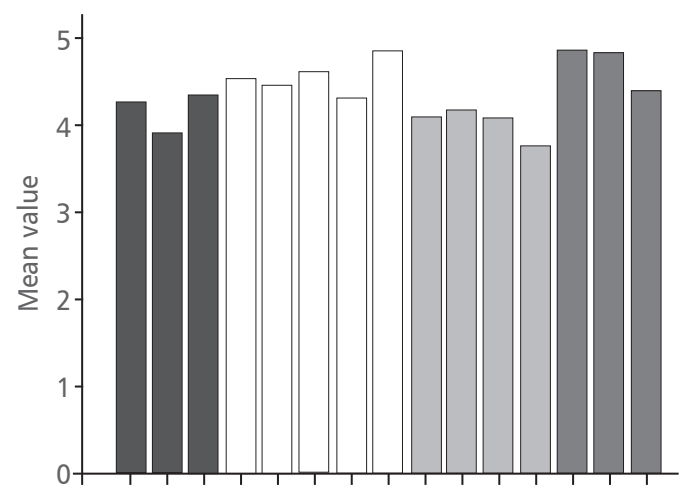

FIGURE 2. Importance of ecosystem services, assigned by students to forests: provisioning (A), regulating (B), cultural (C) and supporting (D) services. Specific ecosystem services are described in Table 1.

Students with more frequent experiences in forest placed more importance on cultural services; they especially recognized the value of forests as a place to be physically active, to

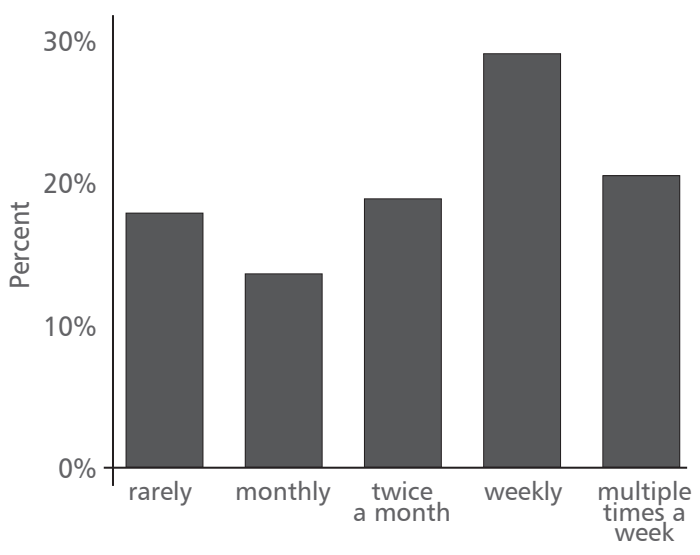

Frequency

FIGURE 3. Students' frequency of experiences in forests.

exercise, and for relaxation and deep thinking (Table 1). They also placed more importance on regulating services, especially for production of clean water and air. More frequent forest visitors

TABLE 1. Influence of student's frequency of experiences in forest has on the importance assigned to forest ecosystem services.

\begin{tabular}{lllc}
\hline & Forest ecosystem services & Code & rs \\
\hline Provisioning services & Produces timber & A1 & -0.047 \\
& Produces food & A2 & $0.100^{*}$ \\
& Produces fuel & A3 & -0.012 \\
\hline Regulating services & Regulates the climate & B1 & $0.107^{*}$ \\
& Protects against natural hazards & B2 & 0.002 \\
& Produces clean water & B3 & $0.126^{*}$ \\
& Soil production & B4 & 0.078 \\
& Produces clean air & B5 & $0.102^{*}$ \\
\hline Cultural services & Is a place for exercise & C1 & $0.260^{* *}$ \\
& Is a place for relaxation and deep thinking & C2 & $0.175^{* *}$ \\
& Is a place for physical activities & C3 & $0.156^{* *}$ \\
& Is a place of aesthetic value & C4 & 0.043 \\
\hline Supporting services & Habitat for animal species & D1 & 0.087
\end{tabular}

$* \alpha=0.05, * * \alpha=0.01$ 
TABLE 2. Influence of student's gender on the importance assigned to forest ecosystem services.

\begin{tabular}{|c|c|c|c|c|c|c|c|}
\hline \multicolumn{2}{|c|}{ Forest ecosystem services } & \multirow{3}{*}{$\begin{array}{c}\text { Code } \\
\text { A1 }\end{array}$} & \multirow{3}{*}{$\begin{array}{c}\text { Gender } \\
\text { female } \\
\text { male }\end{array}$} & \multirow{2}{*}{$\begin{array}{c}\text { Mean } \\
4.27\end{array}$} & \multirow{2}{*}{$\begin{array}{c}\text { SD } \\
0.70\end{array}$} & \multirow{3}{*}{$\frac{\mathbf{U}}{18098.50}$} & \multirow{3}{*}{$\frac{p \text {-value }}{0.852}$} \\
\hline Provisioning & Produces timber & & & & & & \\
\hline & & & & 4.26 & 0.79 & & \\
\hline & Produces food & $\mathrm{A} 2$ & female & 3.96 & 0.91 & 16583.50 & 0.107 \\
\hline & & & male & 3.77 & 1.05 & & \\
\hline & Produces fuel & A3 & female & 4.37 & 0.71 & 18194.00 & 0.871 \\
\hline & & & male & 4.34 & 0.76 & & \\
\hline \multirow{10}{*}{$\begin{array}{l}\text { Regulating } \\
\text { services }\end{array}$} & Regulates the climate & B1 & female & 4.53 & 0.64 & 17425.50 & 0.534 \\
\hline & & & male & 4.47 & 0.69 & & \\
\hline & $\begin{array}{l}\text { Protects against natural } \\
\text { hazards }\end{array}$ & B2 & female & 4.44 & 0.68 & 16873.00 & 0.306 \\
\hline & & & male & 4.37 & 0.70 & & \\
\hline & Produces clean water & B3 & female & 4.64 & 0.64 & 15970.50 & 0.074 \\
\hline & & & male & 4.53 & 0.66 & & \\
\hline & Soil production & B4 & female & 4.31 & 0.65 & 17177,50 & 0.759 \\
\hline & & & male & 4.22 & 0.87 & & \\
\hline & Produces clean air & B5 & female & 4.86 & 0.39 & 18033.00 & 0.487 \\
\hline & & & male & 4,84 & 0,38 & & \\
\hline \multirow{8}{*}{$\begin{array}{l}\text { Cultural } \\
\text { services }\end{array}$} & Is a place for exercise & $\mathrm{C} 1$ & female & 4.14 & 0.70 & 16732.50 & 0.128 \\
\hline & & & male & 3.94 & 0.96 & & \\
\hline & $\begin{array}{l}\text { Is a place for relaxation } \\
\text { and deep thinking }\end{array}$ & $\mathrm{C} 2$ & female & 4.22 & 0.79 & 15501.00 & $0.005^{* *}$ \\
\hline & & & male & 3.91 & 1.03 & & \\
\hline & $\begin{array}{l}\text { Is a place for physical- } \\
\text { sport activities }\end{array}$ & $\mathrm{C} 3$ & female & 4.12 & 0.76 & 17446.00 & 0.445 \\
\hline & & & male & 4,01 & 0,95 & & \\
\hline & $\begin{array}{l}\text { Is a place of aesthetic } \\
\text { value }\end{array}$ & $\mathrm{C} 4$ & female & 3.81 & 0.86 & 17965.50 & 0.960 \\
\hline & & & male & 3.73 & 1.12 & & \\
\hline \multirow[t]{6}{*}{$\begin{array}{l}\text { Supporting } \\
\text { services }\end{array}$} & $\begin{array}{l}\text { Habitat for animal } \\
\text { species }\end{array}$ & D1 & female & 4.89 & 0.33 & 17279.00 & 0.064 \\
\hline & & & male & 4.78 & 0.55 & & \\
\hline & Habitat for plant species & D2 & female & 4.82 & 0.47 & 18107.50 & 0.590 \\
\hline & & & male & 4.80 & 0.47 & & \\
\hline & $\begin{array}{l}\text { Habitat for mushroom } \\
\text { species }\end{array}$ & D3 & female & 4.41 & 0.78 & 18045.00 & 0.657 \\
\hline & & & male & 4.34 & 0.88 & & \\
\hline
\end{tabular}

$* \alpha=0.05, * * \alpha=0.01$ 
also recognized importance of forest for food production. However, there were no significant differences in students' attitudes for supporting services, like the value of forest as habitat for animals and plants.

The importance assigned to forest as a place for relaxation and deep thinking in the group of female students was significantly higher than the group of male students $(U=15501, p=0.004)$ (Table 2). Other gender differences were not significant.

\section{DISCUSSION}

Students acknowledged the high benefits of ecosystem services provided by forests. Results confirm that concept of ecosystem services is an effective means of communication stressing our dependence on ecological life support systems [8].

Interestingly, they placed the highest importance on supporting and regulating ecosystem services and the lowest on cultural services, even though the most frequent reasons for their visiting of the forests were cultural services (e.g. walking, running, relaxation). Result is contradictory to findings by Gao with others [14], where a local residents in SE China highly valued forest cultural services. However, in the study focusing on trade-offs between fire prevention and provision of some forest ecosystem services (e.g. recreation, water purification, animal and plant diversity) was found that water purification (i.e. regulating service) followed by animal and plant diversity were considered as the most important for the welfare of the Slovenian population [12]. In addition, policy and decision makers from Slovenia recognized watershed function, water purification and air purification (referring to regulating services in the present study) as the most important ecosystem services, followed by wildlife and biodiversity protection (referring to supporting services in the present study) [13].

Present study shows that students with more frequent visits to forests have higher valuations of cultural services, which could be explained by place attachment theory [26]. This theory describes a functional attachment to a specific place that can influence the perception of social and environmental site conditions [27]. In addition, more frequent presence in the forests positively influenced on students' valuations of regulating services and food production provided by forests. Explanation could be that the human experiences in natural environments contributes to ecological literacy and more complex assessment of the environmental properties and changes [28].

Some empirical studies confirm that females were more supportive of the environment and nature then males [e.g. 29, 30] while others indicate a more protective stance among men than women or lack of a substantial association in the vast majority of cases [e.g. 31, 32]. In our study gender differences were not significant except in the valuation of forest as a place for relaxation and deep thinking, where female students were more supportive than male students.

\section{CONCLUSIONS}

Findings of the study could be summarized into three main conclusions: a) students placed the highest importance on forest ecosystem supporting and regulating services, particularly production of clean air and water and habitat for animal and plant species; b) students visit forests mainly for recreation purposes; c) gender influenced only the evaluation of forest as a place for relaxation and deep thinking, whereas female students put a higher value on those services and that d) more frequent visits to forest positively influenced students' attitudes toward cultural services.

Forest managers are facing challenges in balancing the demands for forest social services raised by the general public and forest productive services in Central and South-east Europe today [13]. The results of the study show that supporting (e.g. habitat for animal and plant species) and regulating (e.g. clean air production) services in forest management 
should be particularly emphasised, as shown also by Mavsar et al. [12] and Vuletić et al. [13]. Caution should be exercised in generalizing the results of this study, because only secondary school students from one region in Slovenia were considered. Nevertheless, the findings and methodological approach could be a useful basis for the further research of people's attitudes towards forests and its management.

\section{REFERENCES}

1. GUO Z, XIAO X, LI D 2000 An Assessment of Ecosystem Services: Water Flow Regulation and Hydroelectric Power Production. Ecol Appl 10 (3): 925-936. DOI: http://dx.doi.org/10.1890/10510761(2000)010[0925:AAOESW]2.0.CO;2

2. ARMSON D, STRINGER P, ENNOS A R 2012 The effect of tree shade and grass on surface and globe temperatures in an urban area. Urban For Urban Gree 11 (3): 245-255. DOI: http://dx.doi. org/10.1016/j.ufug.2012.05.002

3. MCDONALD $A$ G, BEALEY $W$ J, FOWLER $D$, DRAGOSITS U, SKIBA U, SMITH R I, DONOVAN R G, BRETT H E, HEWITT C N, NEMITZE 2007 Quantifying the effect of urban tree planting on concentrations and depositions of PM10 in two UK conurbations. Atmos Environ 41 (38): 8455-8467. DOI: http:// dx.doi.org/10.1016/j.atmosenv.2007.07.025

4. ALVEY A A 2006 Promoting and preserving biodiversity in the urban forest. Urban For Urban Gree 5 (4): 195-201. DOI: http://dx.doi. org/10.1016/j.ufug.2006.09.003

5. MILLENNIUM ECOSYSTEM ASSESSMENT 2005 Ecosystems and Human Well-Being: Synthesis. Island Press, Washington, DC, USA, 281 p. URL: http://www. millenniumassessment.org/documents/document.356.aspx.pdf (12 January 2014)

6. GÓMEZ-BAGGETHUN E, DE GROOT R, LOMAS $P$ L, MONTES C 2010 The history of ecosystem services in economic theory and practice: from early notions to markets and payment schemes. Ecol Econ 69 (6): 1209-1218. DOI: http://dx.doi. org/10.1016/j.ecolecon.2009.11.007

\section{Acknowledgments}

This study was supported by ManFor C. BD project: "Managing forests for multiple purposes: carbon, biodiversity and socio-economic wellbeing" (LIFE09ENV/IT/000078), the Program group Forest biology, ecology and technology (0404-501), financed by the Ministry of Education, Science, Culture and Sport, Republic of Slovenia. We thank to Ms. Marta Stopar, all the teachers who conducted questioning and students for completing the questionnaires.

7. COSTANZA $R$, D'ARGE $R$, DE GROOT $R$, FARBER $S$, GRASSO M, HANNON B, LIMBURG $K$, NAEEM $S$, O'NEILL R V, PARUELO J, RASKIN R G, SUTTON $P$, VAN DEN BELT M 1997 The value of the world's ecosystem services and natural capital. Nature 387 (6630): 253-260. DOI: http://dx.doi. org/10.1038/387253a0

8. DE GROOT R S, WILSON M, BOUMANS R M J 2002 A typology for the classification, description and valuation of ecosystem functions, goods and services. Ecol Econ 41: 393-408. DOI: http://dx.doi. org/10.1016/S0921-8009(02)00089-7

9. FOREST EUROPE, UNECE, FAO 2011 State of Europe's Forests 2011. Status and Trends in Sustainable Forest Management in Europe. Ministerial Conference on the Protection of Forests in Europe, Forest Europe Liaison Unit Oslo, Norway, 337 p. URL: http://www.unece.org/fileadmin/DAM/ publications/timber/Forest Europe_report_2011. web.pdf (15 January 2014)

10. NATIONAL ASSEMBLY OF THE REPUBLIC OF SLOVENIA 2007 Resolution on National Forest Programme (in Slovenian). Official Gazette 111/2007, Ljubljana, Slovenia. URL: http://www. pisrs.si/Pis.web/pregledPredpisa?id=RESO56 $\quad(15$ January 2014)

11. NATIONAL ASSEMBLY OF THE REPUBLIC OF 2010 Act on forests (in Slovenian). Official Gazette. 30/1993, 13/1998, 67/2002, 115/2006, 110/2007, 106/2010, Ljubljana, Slovenia. URL: http://pisrs.si/ Pis.web/pregledPredpisa?id=ZAKO270 (15 January 2014)

12. MAVSAR R, JAPEU A, KOVAČ M Trade-offs between fire prevention and provision of ecosystem services in Slovenia. Forest Policy Econ 29: 62-69. DOI: http://dx.doi.org/10.1016/.j.forpol.2012.10.011 
13. VULETIĆ D, POTOČIĆ N, KRAJTER S, SELETKOVIĆ I, FÜRST C, MAKESCHIN F, GALIĆ Z, LORZ C, MATIJAŠIČ D, ZUPANIČ M, SIMONČIČ P, VACIK H 2010 How Socio-Economic Conditions Influence Forest Policy Development in Central and SouthEast Europe. Environ Manage 46 (6): 931-940. DOI: http://dx.doi.org/10.1007/s00267-010-9566-3

14. GAO H, OUYANG Z, ZHENG H, BLUEMLING B 2013 Perception and attitudes of local people concerning ecosystem services of culturally protected forests. Acta Ecologica Sinica 33 (3): 756-763. DOI: http:// dx.doi.org/10.5846/stxb201203260412

15. LINDEMANN-MATTHIES P, KELLER D, LI X, SCHMID B 2014 Attitudes toward forest diversity and forest ecosystem services - a cross-cultural comparison between China and Switzerland. J Plant Ecol-UK 7 (1): 1-9. DOI: http://dx.doi.org/10.1093/jpe/rtt015

16. MOYER J M, OWEN R J, DUINKER P N 2008 Forest values: A framework for old-growth forest with implications for other forest conditions. The Open Forest Science Journal 1: 27-36. DOI: http://dx.doi. org/10.2174/1874398600801010027

17. OWEN R J, DUINKER P N, BECKLEY T M 2009 Capturing old-growth values for use in forest decision-making. Environ Manage 43 (2): 237-248. DOI: http://dx.doi.org/10.1007/s00267-008-9133-3

18. SMITH J W, SIDERELIS C, MOORE R L, ANDERSON D H 2012 The effects of place meanings and social capital on desired forest management outcomes: A stated preference experiment. Landscape Urban Plan 106 (2): 207-218. DOI: http://dx.doi. org/10.1016/j.landurbplan.2012.03.009

19. MACURA B, ZORONDO-RODRÍGUEZ F, GRAUSATORRAS M, DEMPS K, LAVAL M, GARCIA C A, REYES-GARCÍA V 2011 Local community attitudes toward forests outside protected areas in India. Impact of legal awareness, trust, and participation. Ecol Soc 16 (3): 10. DOI: http://dx.doi.org/10.5751/ ES-04242-160310

20. KREK J, METLAK M (eds) 1996 White paper on education in the Republic of Slovenia. Ministry of Education and Sport, Ljubljana, Slovenia, $520 \mathrm{p}$

21. KUTNAR L, VESELIČ Ž, DAKSKOBLER I, ROBIČ D 2012 Typology of Slovenian forest sites according to ecological and vegetation conditions for the purposes of forest management (in Slovenian with English summary). Gozdarski vestnik 70 (4): 195214
22. SLOVENIA FOREST SERVICE 2012 Gozdnogospodarski načrt gozdnogospodarskega območja Tolmin (2011-2020) (in Slovenian). Ur. I. RS št. 87/2012, 216 p. URL: http://www.mko.gov. si/fileadmin/mko.gov.si/pageuploads/GGO/ Tolmin/01 TOLMIN 2011-2020.pdf (15 February 2014)

23. WRABER T 1969 Floristika v Sloveniji v letu 1968. Biološki vestnik 17: 173-192

24. STATISTICAL OFFICE OF THE REPUBLIC OF SLOVENIA 2013 Demography and Social Statistics. URL: http://www.stat.si/eng/tema demografsko izobrazevanje.asp (8 April 2014)

25. LIKERT R $1932 \mathrm{~A}$ technique for the measurement of attitudes. Archives of psychology 140

26. LEWICKA M 2011 Place attachment: How far have we come in the last 40 years? J Environ Psychol 31 (3): 207-230. DOI: http://dx.doi.org/10.1016/j. jenvp.2010.10.001

27. EDER R, ARNBERGER A 2012 The influence of place attachment and experience use history on perceived depreciative visitor behavior and crowding in an urban national park. Environ Manage 50 (4): 566580. DOI: http://dx.doi.org/10.1007/s00267-0129912-8

28. CLAYTON S, MYERS G 2009 Conservation psychology: Understanding and promoting human care for nature. Wiley-Blackwell, 264 p.

29. TAYLOR N, SIGNAL T D 2005 Empathy and attitudes to animals. Anthrozoös 18 (1): 18-27. DOI: http:// dx.doi.org/10.2752/089279305785594342

30. TORKAR G, MOHAR P, GREGORC T, NEKREP I, HONIGSFELD ADAMIČ M 2010 The conservation knowledge and attitudes of teenagers in Slovenia toward the Eurasian Otter. International Journal of Environmental \& Science Education 5 (3): 341-352

31. HAYES B C 2001 Gender, Scientific Knowledge, and Attitudes toward the Environment: ACross-National Analysis. Polit Res Quart 54 (3): 657-671. DOl: http://dx.doi.org/10.1177/106591290105400309

32. VAN LIERE K D, RILEY E D 1980 The Social Bases of Environ- mental Concern: A Review of Hypotheses, Explanations and Empirical Evidence. Public Opin Quart 44 (2): 181-197. DOI: http://dx.doi. org/10.1086/268583 
